\title{
Melamine Polyphosphate - the Reactive and Additive Flame Retardant for Polyurethane Foams
}

\section{Jacek Lubczak and Renata Lubczak}

\author{
Faculty of Chemistry, University of Technology, Al. Powstańców Warszawy 6, 35-959 Rzeszów, Poland \\ * Corresponding author: E-mail: jml@prz.edu.pl
}

Received: 20-08-2015

\begin{abstract}
Melamine polyphosphate (MPP) was applied as reactive and additive flame retardant for thermally resistant polyurethane foams. MPP was hydroxyalkylated with ethylene and propylene carbonates to get oligoetherols with 1,3,5-triazine ring and phosphorus. The structure and physical properties of the products were studied. The polyurethane foams, (PUFs) obtained from this oligoetherols were self-extinguishing. The addition of powdered MPP into foaming mixture resulted in further decrease of flammability modified PUFs. The MPP-modified PUFs were characterized by physical methods adequate to thermal resistance and flammability of the PUFs. The best MPP-modified PUF showed oxygen index 24.6. All the modified PUFs were remarkably thermally resistant; they could stand long lasting thermal exposure even at $200{ }^{\circ} \mathrm{C}$.
\end{abstract}

Keywords: Melamine polyphosphate, oligoetherols, polyurethane foams, properties, thermal stability, flammability.

\section{Introduction}

Oligoetherols with incorporated 1,3,5-triazine ring (II) can be obtained from melamine (I) and excess alkylene carbonates, like ethylene (EC) or propylene (PC) carbonates: ${ }^{1,2}$

Thermally resistant polyurethane foams (trPUFs) from these polyetherols, water and isocyanates have been obtained. ${ }^{3}$ Classic PUFs undergo decomposition at temperatures above $90{ }^{\circ} \mathrm{C},{ }^{4,5}$ while trPUFs with $1,3,5$-triazine rings are resistant against long lasting heating even at 200 ${ }^{\circ} \mathrm{C}$. ${ }^{6}$ This renders them useful materials as thermal isolators. On the other hand they are flammable, therefore we have undertaken systematic study to decrease the flammability of PUFs based on 1,3,5-triazine ring in order to improve their properties as potential thermoinsulators.

Flame retardation of polyurethanes can be achieved by incorporation elements like chlorine, bromine, phosphorus, nitrogen or silicon into polyurethane or into the oligoetherol substrate. ${ }^{7,8}$ By introduction of flame retardants,<smiles>Nc1nc(N)nc(N)n1</smiles>

(I)

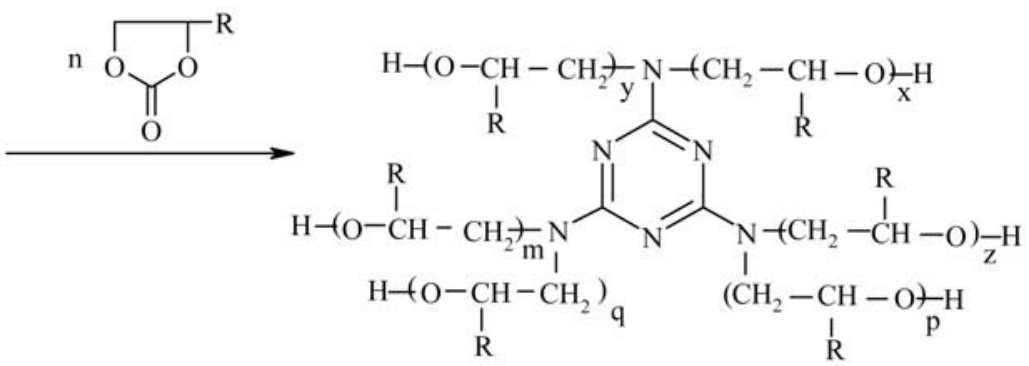

(II)

where: $x+y+z+p+q+m=n R=-H,-\mathrm{CH}_{3}$

Scheme 1. Synthesis of oligoetherols from melamine and alkylene carbonate. 


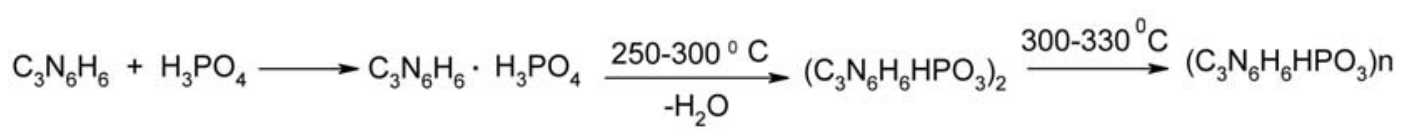

melamine phosphate

melamine pyrophosphate

MPP

Scheme 2. Obtaining of MPP.

in other word antipyrenes, the pyrolysis of polymeric materials as well as flame resistant can be considerably restricted and finally self-extinguishing materials can be obtained. Antipyrenes can be divided into two groups. ${ }^{9}$ namely: (i) reactive retardants, which are incorporated into chemical structure of polymers at the stage of polymer synthesis or cross-linking, and (ii) additive flame retardants, which are incorporated into polymer as nonreacting compounds to form compositions. Introducing phosphorus and nitrogen into polyurethane foams effectively increases the PUFs flame resistance. Especially the simultaneous modification of PUFs with nitrogen and phosphorus is desirable due to synergy between those two elements. ${ }^{10-12}$ Thus, the best known flame retardants are ammonium phosphates and melamine and MPP. ${ }^{13}$ Addition of flame retardants decreases the percentage of flammable parts of composites. Moreover, upon decomposition at $350{ }^{\circ} \mathrm{C}$ the MPP degrades endothermally, and released phosphoric acid deposits on the surface and forms the film, which is the thermal barrier for hest transfer into polymer. ${ }^{14}$ MPP can be obtained by thermal conversion of melamine phosphate into melamine pyrophosphate at $250-300{ }^{\circ} \mathrm{C}$ and further into MPP at $300-330{ }^{\circ} \mathrm{C} .{ }^{13}$

We have described here the results of our attempts on MPP as reactive and additive retardant for PUFs of enhanced thermal stability and increased flammability.

\section{Experimental Section}

\section{1. Synthesis of Oligoetherols from MPP and Alkylene Carbonates}

MPP (16.5 g, 0.08 mole of mers, pure, Zakłady Chemiczne „Alwernia”, Poland), EC (154.9 g, 1.76 mole or 70.4 g, 0.8 mole, pure, Fluka, Buchs, Switzerland) and potassium carbonate as catalyst $(1.6 \mathrm{~g}$ and $0.8 \mathrm{~g}$, respectively) were placed in three-necked $250 \mathrm{~cm}^{3}$ flask equipped with mechanical stirrer, thermometer and reflux condenser. The mixture was heated up to $170-175{ }^{\circ} \mathrm{C}$ while stirred. After completion of the reaction with $70.4 \mathrm{~g} \mathrm{EC}$, the PC (48.9 g, 0.48 mole, pure, Fluka, Buchs, Switzerland) was added and heating was continued. The reaction was monitored by mass balance and by determination of unreacted alkylene carbonate. The products were resin, viscous liquids of brown color. In another synthesis the
MPP (4.1 g, 0.02 mole of mer), PC (30.6 g, 0.3 mole), and $0.3 \mathrm{~g} \mathrm{~K}_{2} \mathrm{CO}_{3}$ were used at $185-190{ }^{\circ} \mathrm{C}$ temperature. In this case the oily product was contaminated with solid, not converted MPP.

\section{2. Analytical Methods}

The course of reaction between MPP and EC or PC was followed by measuring the content of unreacted alkylene carbonate. The samples were treated with $2.5 \mathrm{~cm}^{3}$ of $0.15 \mathrm{M}$ barium hydroxide, vigorously shaken and the excess of barium hydroxide titrated off with $0.1 \mathrm{M} \mathrm{HCl}$ solution. ${ }^{15}$ In obtained products the acid numbers were determined by titration with a standard potassium hydroxide solution and hydroxyl number of the obtained oligoetherols was determined with use of acetic anhydride. ${ }^{16}$ Elemental analysis for C, H, N, were done with EA 1108, Carlo-Erba analyzer. The ${ }^{1} \mathrm{H}-\mathrm{NMR}$ spectra of products were recorded at $500 \mathrm{MHz}$ Bruker UltraShield in DMSO-d 6 with hexamethyldisiloxane as internal standard. IR spectra were registered on PARAGON 1000 FT IR Perkin Elmer spectrometer in $\mathrm{KBr}$ pellets or ATR technique. Thermal analyses of oligoetherols and foams (DTA, DTG and TG) were performed in ceramic crucible at $20-600{ }^{\circ} \mathrm{C}$ temperature range, about $200 \mathrm{mg}$ sample, under air atmosphere with Termowaga TGA/DSC 1 derivatograph, Mettler, recording time 100 minutes, 1/10 DTA amplification, and 1/15 DTG amplification.

\section{3. Physical Properties of Oligoetherols}

Refraction index, density, viscosity, and surface tension of oligoetherols were determined with Abbe refractometer, pycnometer, Höppler viscometer (typ BHZ, prod. Prüfgeratewerk, Germany) and by the detaching ring method, respectively.

\section{4. Foam Preparation}

Oligoetherol (10 g), 2\% water, silicone L-6900 (pure, Houdry Hülls, USA) surfactant, and triethylamine (pure, $\mathrm{POCH}$, Poland) catalyst were placed in $500 \mathrm{~cm}^{3}$ cup, homogenized by stirring, then polymeric diphenylmethane 4,4'-diisocyanate (pMDI, containing 30 mass $\%$ of three-functional isocyanates, Merck, Darmstadt, Germany) was added and the mixture was stirred mechanically at $1800 \mathrm{rpm}$ until creaming started. Other composi- 
tions were also prepared, in which the MPP was added as additive flame retardant after homogenization of oligoetherol, water, silicone and triethylamine. After homogenization of these mixtures the pMDI was added and further the creaming was performed as described above.

\section{5. Studies of Foams}

The apparent density, ${ }^{17}$ water uptake, ${ }^{18}$ dimensional stability in temperature $150{ }^{\circ} \mathrm{C},{ }^{19}$ heat conductance coefficient, heat capacity, and compressive strength ${ }^{20}$ of trPUFs with flame retardants were measured. Thermal resistance of modified foams was determined both by static and dynamic methods. In static method the foams were heated at 150 , 175 and $200{ }^{\circ} \mathrm{C}$ with continuous measurement of mass loss and determination of mechanical properties before and after heat exposure. Thermal resistance was also determined by dynamic method DSC using differential scanning calorimeter type DSC $822^{\mathrm{e}}$ (METTLER TOLEDO), with the following parameters: temperature range $20-200{ }^{\circ} \mathrm{C}$, heating rate $10 \mathrm{deg} / \mathrm{min}$, nitrogen atmosphere, sample mass 10-20 mg, recording time 100 minutes, DTA 1/10 amplification, and DTG 1/15 amplification. Flammability of foams was determined by oxygen inde ${ }^{21}$ and horizontal test according to norm ${ }^{22}$ as follows: the foam samples $(150 \times 50 \times 13 \mathrm{~mm})$ were weighed, located on horizontal support (wire net of $200 \times 80 \mathrm{~mm}$ dimensions) and the line was marked at the distance of $25 \mathrm{~mm}$ from edge. The sample was set on fire from the opposite edge using Bunsen burner with the blue flame of $38 \mathrm{~mm}$ height for $60 \mathrm{~s}$. Then the burner was removed and time of free burning of foam reaching marked line or cease of flame was measured by stopwatch. After that the samples were weighed again.

If the sample was burned totally, the rate of burning was calculated according to the expression:

$$
v=\frac{125}{t_{b}}
$$

If the burning of sample ceased, the following equation was used:

$$
v=\frac{L_{e}}{t_{e}}
$$

where:

$L_{e}$ - the length of burned fragment, measured as the difference 150 minus the length of unburned fragment (in $\mathrm{mm}$ ). According to norms, if the burned fragment has the $125 \mathrm{~mm}$ length, the foam is considered as flammable.

$t_{b}, t_{e}-$ the time of propagation of flame measured at the distance between starting mark up to the end mark or as the time of flame cease.

The mass loss $\Delta m$ after burning was calculated from the formula:

$$
\Delta m=\frac{m_{o}-m}{m_{o}} .100 \%
$$

where $m_{o}$ and $m$ - mean the sample mass before and after burning, respectively.

\section{Results and Discussion}

No hydroxyalkylation of MPP was reported till date, probably due to its insolubility in organic solvents or water. Thus, hydroxyalkylation of MPP cannot be performed by oxiranes in DMSO or DMF, in contrary to melamine. ${ }^{23}$ It is known that azacyclic compounds with nitrogen-attached hydrogen are soluble in alkylene carbonates and react with them resulting in formation of oligoetherols. ${ }^{24}$ We have applied this method to derivatize MPP with EC and PC toward oligoetherols (Table 1). Then the oligoetherols were used to obtain PUFs with 1,3,5-triazine ring and phosphorus incorporated into polymer structure. The oligoetherols

\begin{tabular}{|c|c|c|c|c|c|c|c|}
\hline \multirow[b]{2}{*}{ Entry } & \multirow{2}{*}{$\begin{array}{c}\text { Initial } \\
\text { molar ratio } \\
\text { mMPP } \\
\text { EC: PC }\end{array}$} & \multirow{2}{*}{$\begin{array}{c}\text { Amount } \\
\text { of cata- } \\
\text { lyst }[\mathrm{g} / \mathrm{mol} \\
\text { mMPP] }\end{array}$} & \multicolumn{3}{|c|}{ Reaction conditions } & \multirow{2}{*}{$\begin{array}{c}\text { Number of moles } \\
\text { of AC/ mol } \\
\text { mMPP, } \\
\text { decomposed* }\end{array}$} & \multirow[b]{2}{*}{ Remarks } \\
\hline & & & $\begin{array}{c}\text { Tempe- } \\
\text { rature } \\
{\left[{ }^{\circ} \mathbf{C}\right]}\end{array}$ & $\begin{array}{c}\text { Dissolution } \\
\text { time MPP } \\
{[\mathbf{h}]}\end{array}$ & $\begin{array}{c}\text { Reac- } \\
\text { tion time } \\
{[\text { h] }}\end{array}$ & & \\
\hline 1 & $1: 22: 0$ & 20 & 170 & 3 & 13 & 3 & Dark brown resin \\
\hline 2 & $1: 0: 15$ & 25 & 190 & - & 23 & 7 & $\begin{array}{l}\text { Dark brown product of } \\
\text { unpleasant odor; solid } \\
\text { observed in post- } \\
\text { reaction mixture }\end{array}$ \\
\hline 3 & $1: 10: 6$ & 10 & 175 & 10 & 22 & $\begin{array}{l}1 \text { mole EC } \\
1 \text { mole PC }\end{array}$ & Dark brown resin \\
\hline
\end{tabular}
were synthesized using EC at $170^{\circ} \mathrm{C}$, and $\mathrm{PC}$ at $190^{\circ} \mathrm{C}$.

Table 1. Synthesis conditions of oligoetherols from MPP and alkylene carbonates (AC)

*based upon mass balance

mMPP - mere of melamine polyphosphate, AC -alkylene carbonate 
However, during the synthesis of oligoetherols from $\mathrm{PC}$ is a large weight losses of the reaction mixture by thermal decomposition of PC into carbon dioxide and propylene oxide, which leave the reaction medium. Moreover, in the worked-up post reaction mixture free MPP was found, which in the reaction mixture is suspended in oligoetherol. Such contaminated and undefined oligoetherols were useless substrates to obtain PUFs. Therefore, consecutive syntheses of oligoetherols were applied; first the MPP was reacted with EC and in the second step the PC was used (Table 1). The amount of EC and PC were minimized to obtain oligoetherols of low viscosity, enabling further homogenization with isocyanates at foaming step. When EC and PC were minimized, the contributions of 1,3,5-triazine ring and phosphorus in the oligoetherol were obviously higher. The obtained oligoetherols were resin-type products. Two kinds of oligoetherols were obtained: with EC only and EC and PC, at initial molar ratio of reagents: mMPP:EC $=1: 22$, and mMPP:EC:PC $=$
1:10:6 (mMPP - mere of melamine polyphosphate). Based on mass balance, elemental analysis and hydroxyl numbers in products: 469 and $490 \mathrm{mg} \mathrm{KOH} / \mathrm{g}$, respectively (Table 2) it has been concluded that in isolated products the number of oxyalkylene groups per one mMPP was 1:19 and 1:9:5 (Table 2), respectively. Obviously some decomposition of alkylene carbonates in synthetic conditions took place. The scheme of synthesis is summarized as follows:

The proposed structure of oligoetherols was verified by IR and ${ }^{1} \mathrm{H}-\mathrm{NMR}$ spectra of isolated products. In the IR spectrum of MPP (Fig. 1) the symmetric and asymmetric $v(\mathrm{~N}-\mathrm{H})$ broad bands at $3400-3100 \mathrm{~cm}^{-1}$ are present. The deformation bands of amine group are present in $1704-1550 \mathrm{~cm}^{-1}$ region. The valence bands of $\mathrm{C}=\mathrm{N}$ in melamine are in the $1690-1410 \mathrm{~cm}^{-1}$ region, while $1,3,5$ triazine ring bands occur at $782 \mathrm{~cm}^{-1}$. Phosphate group bands are at $1338 \mathrm{~cm}^{-1}$ for free $\mathrm{P}=\mathrm{O}$ group, while the band at $1272 \mathrm{~cm}^{-1}$ belongs to hydrogen-bonded phosphate. The

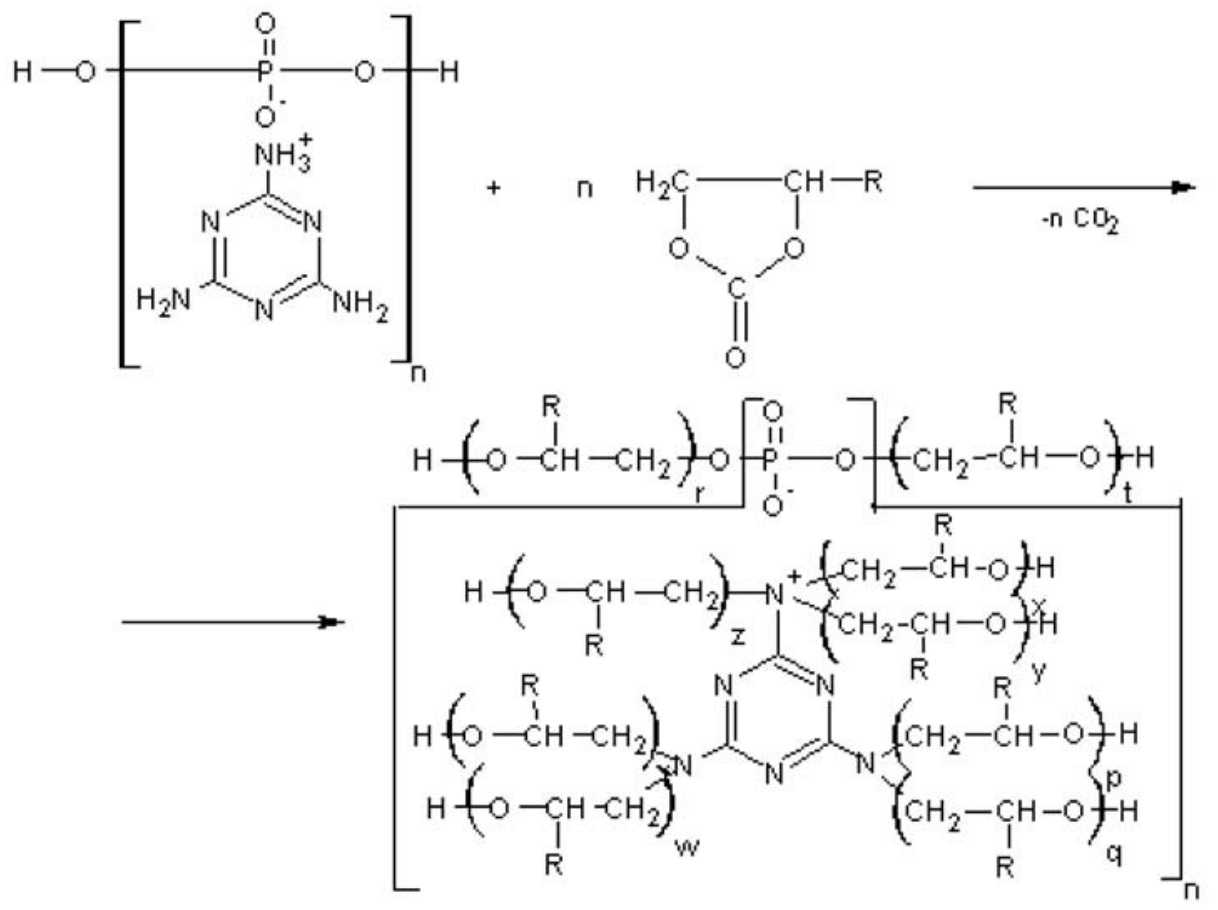

where: $f+p+r+t+q+w+x+y+z=n$

$n$-numbers of moles of alkylene carbonate which reacted with 1 mole of mMPP.

Scheme 3. Synthesis of oligoetherols from melamine polyphosphate and alkylene carbonates.

Table 2. Elemental analyses, acid and hydroxyl numbers of obtained oligoetherols

\begin{tabular}{|c|c|c|c|c|c|c|c|c|c|}
\hline \multirow{3}{*}{$\begin{array}{l}\text { Initial molar } \\
\text { ratio mMPP : } \\
\text { EC : PC }\end{array}$} & \multirow{3}{*}{$\begin{array}{c}\text { Molar ratio mMPP; } \\
\text { oxyalkylene groups from } \\
\text { z EC and PC in product }\end{array}$} & \multicolumn{6}{|c|}{ Elemental analysis [\% mas] } & \multirow{3}{*}{$\begin{array}{c}\text { Acidic } \\
\text { number } \\
{[\mathrm{mg} \mathrm{KOH} / \mathrm{g}]}\end{array}$} & \multirow{3}{*}{$\begin{array}{c}\text { Hydroxyl } \\
\text { number } \\
{[\mathrm{mg} \mathrm{KOH} / \mathrm{g}]}\end{array}$} \\
\hline & & & Calc. & & & found & & & \\
\hline & & C & $\mathbf{H}$ & $\mathbf{N}$ & C & $\mathbf{H}$ & $\mathbf{N}$ & & \\
\hline $1: 22: 0$ & $1: 19: 0$ & 46.42 & 8.02 & 7.92 & 46.66 & 8.38 & 7.89 & 8.6 & 469 \\
\hline $1: 10: 6$ & 1:9:5 & 47.47 & 8.24 & 9.23 & 47.76 & 8.44 & 9.37 & 12.9 & 490 \\
\hline
\end{tabular}


$\mathrm{P}-\mathrm{O}-\mathrm{H}$ group broad band is at $2700-2600 \mathrm{~cm}^{-1}$ and the band from $-\mathrm{NH}_{3}{ }^{+}$cation at $2700-2250 \mathrm{~cm}^{-1}$. The amine group and ammonium cation bands at the 3400-3100 $\mathrm{cm}^{-1}$ and $2700-2600 \mathrm{~cm}^{-1}$ region respectively are absent in the IR spectra of products of reaction between MPP and alkylene carbonates (Fig. 2). Instead, the $v(\mathrm{O}-\mathrm{H})$ bands are present. Also the deformation amine bands at $1660-1570 \mathrm{~cm}^{-1}$ are absent in spectra of products, while $\mathrm{C}=\mathrm{N}$ bands remain, indicating the presence of 1,3,5-triazine ring in oligoetherols. The bands from $\mathrm{P}-\mathrm{O}-\mathrm{H}$ and $\mathrm{NH}_{3}^{+}$at $2700-2250 \mathrm{~cm}^{-1}$ disappear in the products, indicating that both amine groups of melamine and phosphate

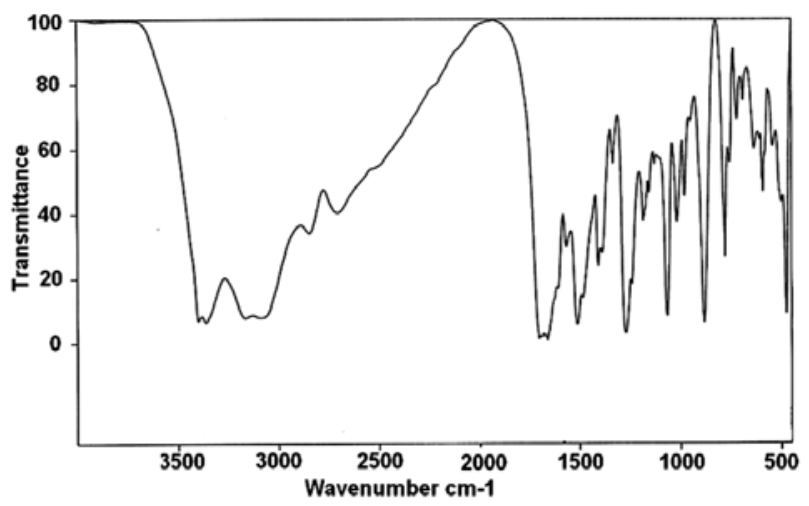

Fig. 1. IR spectrum of MPP

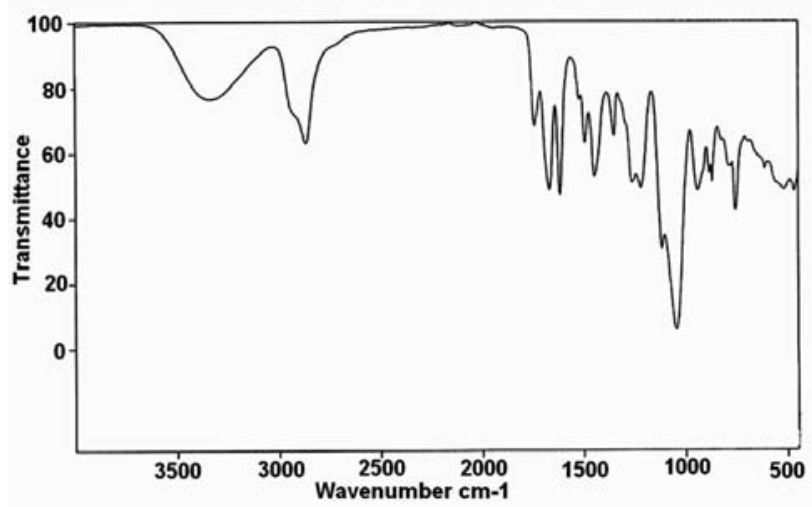

Fig. 2. IR spectrum of oligoetherol obtained from mMPP:EC=1:22

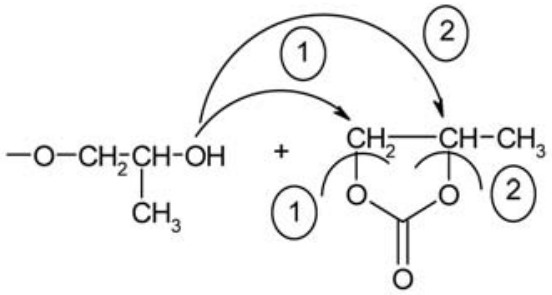

Scheme 4. PC ring-opening reactions. residue $\mathrm{OH}$ underwent hydroxyalkylation with alkylene carbonates. Low values of acidic number $(\mathrm{AN}=8.6-12.9$ $\mathrm{mg} \mathrm{KOH} / \mathrm{g}$ ) evidence the absence or low content of acidic groups derived from MPP hydrolysis during titration. Nonetheless, in the IR spectra of oligoetherols the bands at 1359-1353 and $1267-1265 \mathrm{~cm}^{-1}$ attributed to free and hydrogen-bonded $\mathrm{P}=\mathrm{O}$ groups clearly evidence the presence of phosphate in the products, similarly as the band at $752-759 \mathrm{~cm}^{-1}$ region from 1,3,5-triazine ring. Moreover, methylene and methyl group signals at 2860-2970 $\mathrm{cm}^{-1}$ appear in IR spectra of products. These new bands belong to the groups formed upon hydroxyalkylation of MPP. High intensity bands at $1042-1047 \mathrm{~cm}^{-1}$ indicate the presence of ether bond in oligoetherol due to alkylene carbonate ring opening reaction.

The ${ }^{1} \mathrm{H}$-NMR spectra of oligoetherols obtained from MPP and EC are simple (Fig. 3 and 4). The multiplets in the 3.1-3.6 ppm region from methylene protons in oxyethylene groups are diagnostic. The broad singlet at 4.6-4.7 ppm was attributed to -O-H proton by selective deuteration experiment. Olefinic resonance at 4.3 ppm had very low intensity indicating that dehydration of oligoetherols during demanding synthetic conditions was a minor side reaction. In the ${ }^{1} \mathrm{H}-\mathrm{NMR}$ spectra of oligoetherols obtained from MPP, EC, and PC (Fig. 4) additional signals from methyl protons are present at 0.95-1.1 ppm region. In fact there are two resonances, one from normal and another one from abnormal PC

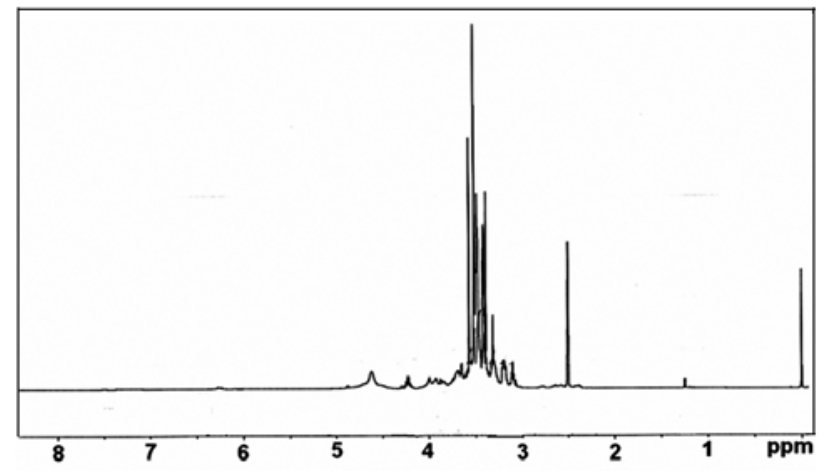

Fig. 3. ${ }^{1} \mathrm{H}-\mathrm{NMR}$ spectrum of oligoetherol obtained from mMPP:EC $=1: 22$ 


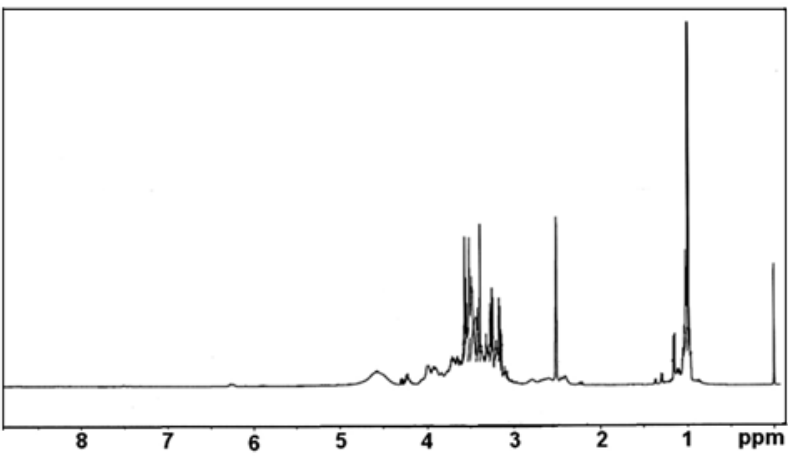

Fig. 4. ${ }^{1} \mathrm{H}-\mathrm{NMR}$ spectrum of oligoetherol from mMPP:EC:PC $=1: 10: 6$

ring-opening reactions: ${ }^{25}$ By integration of these two resonances one can find that there is ca $14 \%$ of abnormal pro-duct.

Relevant physical properties of oligoetherols were determined, like refraction index density, viscosity, and surface tension (Fig. 5-7). All the properties showed typical temperature dependences. The product containing oxypropylene groups have lower density than those obtained from EC. Also the viscosity of oligoetherol with PC is lower than that with EC, which enables homogenization of foaming composition suitable for obtaining PUFs. Refraction indexes of oligoetherols in temperature $20^{\circ} \mathrm{C}$ are similar: 1.5010 for the oligoetherol obtained from $\mathrm{m}$ MPP:EC $=1: 22$ and 1.5019 for the oligoetherol obtained from mMPP:EC:PC = 1:10:6.

We have tested the obtained oligoetherols as substrates for PUFs. We were interested in the effect of flame retardance of PUFs obtained from the oligoetherols MPP-modified as reactive retardant (MPP-PUFs). We have optimized the amount of isocyanate (pMDI) and catalyst for both kinds of MPP-PUFs: those obtained from

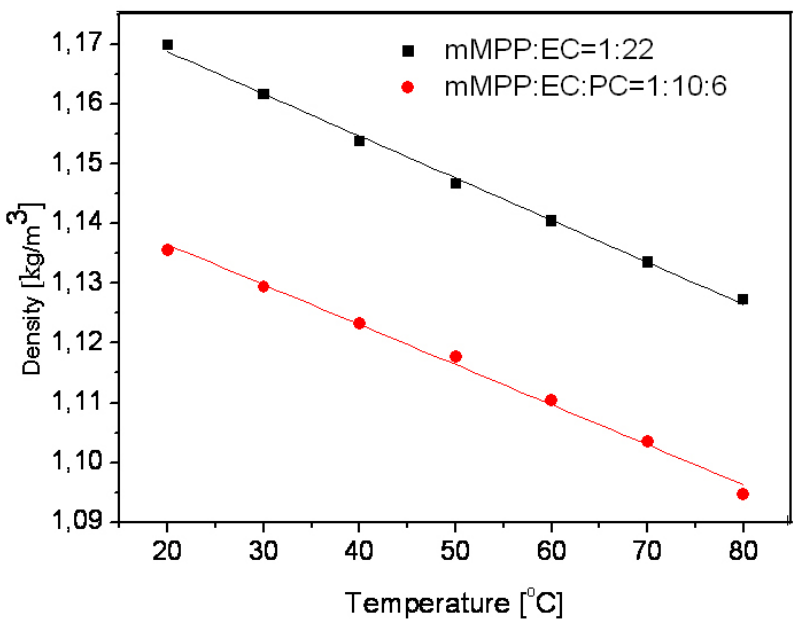

Fig. 5. Dependence of density in function of temperature for the oligoetherols obtained in molar ratio as shown in insert.

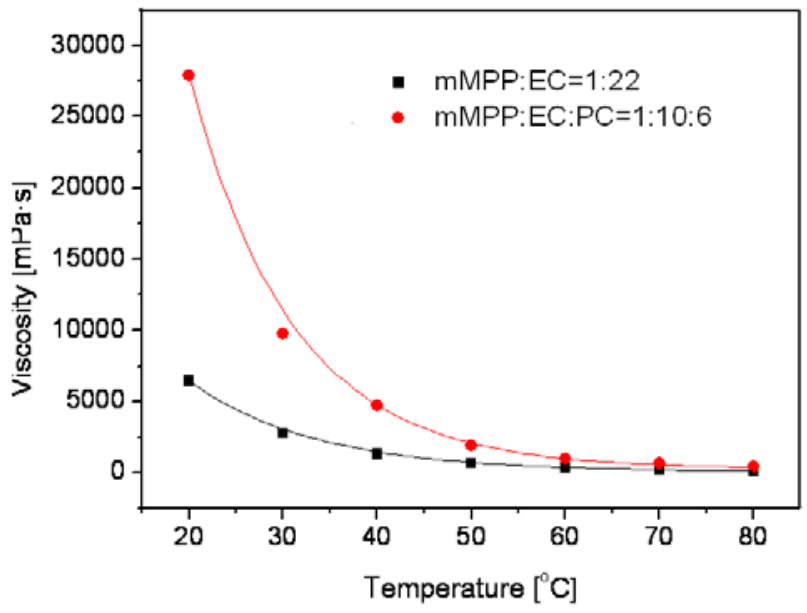

Fig. 6. Dependence of viscosity in function of temperature for the oligoetherols obtained in molar ratio as shown in insert.

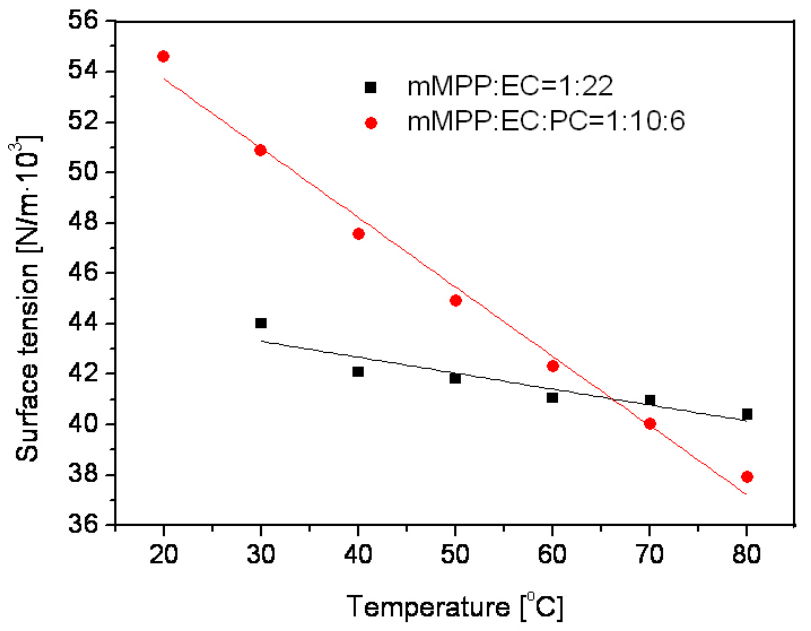

Fig. 7. Dependence of surface tension in function of temperature for the oligoetherols obtained in molar ratio as shown in insert.

$\mathrm{EC}$ and $\mathrm{EC}+\mathrm{PC}$ as substrates for oligoetherol. We have found that the best properties of MPP-PUFs were obtained when amount of pMDI in foaming mixture, given as molar ratio of isocyanate to hydroxyl groups $(\mathrm{NCO} / \mathrm{OH})$ in foaming mixture was 1.2 (isocyanate coefficient, Table 3, compositions 3 and 7). Considering the optimization of water, the $1 \%$ water in foaming mixture led to low foaming, more than $2 \%$ led to fragile MPP-PUFs, therefore $2 \%$ was the optimum amount. The optimized amount of catalyst was $3.3 \mathrm{~g}$ catalyst per $100 \mathrm{~g}$ oligoetherol in EC-based compositions, and $6 \mathrm{~g}$ in EC-PC - based compositions (Table 3, compositions 3 and 7). Optimized surfactant percentage was between 1.0 and $1.2 \%$. Creaming times were short (below $30 \mathrm{sec}$ ); in fully optimized conditions they were within 19-23 seconds. Growing time for optimized compositions was 53 and 26 seconds, respectively. After growing the MPP-PUFs had dry surface. 
Table 3. The influence of composition on foaming process and characteristics of PUFs

\begin{tabular}{|c|c|c|c|c|c|c|c|c|c|c|}
\hline \multirow{2}{*}{$\begin{array}{l}\text { Initial molar } \\
\text { ratiom } \\
\text { MPP:EC: } \\
\text { PC }\end{array}$} & \multirow{2}{*}{$\begin{array}{c}\text { Comp. } \\
\text { No }\end{array}$} & \multicolumn{5}{|c|}{$\begin{array}{l}\text { Amount of co-substrate } \\
\text { [g/100g oligoetherol] }\end{array}$} & \multicolumn{3}{|c|}{ Foaming Process } & \multirow[b]{2}{*}{$\begin{array}{c}\text { Characteristics } \\
\text { of foams }\end{array}$} \\
\hline & & pMDI & $\begin{array}{l}\text { Lg//00g } \\
\text { TEA }\end{array}$ & $\begin{array}{l}\text { ollgoe } \\
\text { sili- } \\
\text { kone }\end{array}$ & $\begin{array}{c}\text { therol] } \\
\text { MPP }\end{array}$ & $\begin{array}{c}\text { Molar } \\
\text { ratio } \\
\mathrm{NCO} / \mathrm{OH}\end{array}$ & $\begin{array}{c}\text { Time of } \\
\text { creaming } \\
{[\mathrm{s}]}\end{array}$ & $\begin{array}{c}\text { Time of } \\
\text { expanding } \\
{[\mathrm{s}]}\end{array}$ & $\begin{array}{l}\text { Time of } \\
\text { drying }\end{array}$ & \\
\hline \multirow{3}{*}{ 1:22:0 } & 1 & 160 & 11.3 & 2.4 & 0 & 1.4 & 10 & 10 & Imm. & Rigid \\
\hline & 2 & 140 & 7.9 & 2.4 & 0 & 1.2 & 12 & 5 & Imm. & Semirigid \\
\hline & $3 *$ & 140 & 3.3 & 1.0 & 0 & 1.2 & 23 & 53 & Imm. & Regular pores, rigid \\
\hline \multirow{5}{*}{ 1:10:6 } & 4 & 112 & 3.5 & 2.4 & 0 & 0.9 & 13 & 21 & Imm. & Irregular pores \\
\hline & 5 & 140 & 6.0 & 1.6 & 0 & 1.0 & 30 & 49 & Very long & Low foaming \\
\hline & 6 & 140 & 5.3 & 1.6 & 0 & 1.0 & 24 & 35 & 10 & Large pores \\
\hline & $7 *$ & 160 & 6.0 & 1.2 & 0 & 1.2 & 19 & 26 & 10 & Regular pores, rigid \\
\hline & 8 & 160 & 5.0 & 1.2 & 0 & 1.2 & 25 & 29 & 15 & Large pores \\
\hline \multirow{6}{*}{ 1:22:0 } & 9 & 130 & 5.3 & 2.4 & 45 & 1.6 & 18 & 79 & Very long & Viscous surface \\
\hline & 10 & 116 & 4.9 & 2.2 & 45 & 1.6 & 12 & 26 & Imm. & Rigid \\
\hline & $11^{*}$ & 120 & 4.7 & 1.9 & 45 & 1.5 & 14 & 16 & Imm. & Regular pores, rigid \\
\hline & 12 & 124 & 5.3 & 2.9 & 55 & 1.6 & 16 & 37 & Imm. & Viscous surface, shrinkage \\
\hline & 13 & 120 & 4.0 & 2.4 & 55 & 1.0 & 14 & 46 & 10 & Small shrinkage \\
\hline & $14 *$ & 112 & 6.6 & 2.4 & 55 & 0.9 & 12 & 10 & Imm. & Regular pores, rigid \\
\hline \multirow{5}{*}{ 1:10:6 } & 15 & 117 & 3.7 & 1.6 & 45 & 1.5 & 14 & 16 & Imm. & Large pores \\
\hline & $16^{*}$ & 117 & 3.4 & 1.6 & 45 & 1.3 & 18 & 39 & Imm. & Regular pores, rigid \\
\hline & 17 & 120 & 5.3 & 1.6 & 55 & 0.9 & 18 & 72 & Very long & Breaks while growing \\
\hline & 18 & 108 & 5.3 & 1.6 & 55 & 0.8 & 13 & 47 & Imm. & Breaks while growing \\
\hline & $19 *$ & 104 & 5.0 & 1.6 & 55 & 0.7 & 14 & 25 & Imm. & Regular pores, rigid \\
\hline
\end{tabular}

\footnotetext{
$2 \%$ of water in relation to mass of oligoetherol was used

* composition obtained under optimized foaming conditions; pMDI - polymeric diphenylmethane isocyanate, TEA - triethylamine

Time of Creaming: the time elapsed from the moment of mixing to the start of volume expansion;

Time of Expanding: the time from the start of expansion to the moment of reaching the sample final volume;

Time of Drying: the time from reaching by the sample its final volume to the moment of losing its surface adhesion
}

The apparent density, water uptake and linear dimensions before and after thermal exposure of MPP-PUFs at $150{ }^{\circ} \mathrm{C}$ were determined (Table 4 , compositions 3 and 7). It has been found that apparent density of PUFs was within $59.7-63.7 \mathrm{~kg} / \mathrm{m}^{3}$. Water uptake was maximum $11.4 \%$, which indicated that closed pores dominated in obtained materials. Linear dimension stability was monitored after exposure of MPP-PUFs at $150{ }^{\circ} \mathrm{C}$ and it was below $0.5 \%$ in case of PUF obtained from oligoetherol $\mathrm{m}$ MPP:EC:PC 1:10:6, and $7.6 \%$ in case PUFs from mMPP:EC $=1: 22$ after 48 hours exposure. The obtained $p$ UFs had typical heat conductivity within $0.026-0.043$ $[\mathrm{W} / \mathrm{m} \cdot \mathrm{K}]$ (table 4, compositions 3 and 7). Heat capacity of PUFs was $(83-111) 10^{3} \mathrm{~kJ} / \mathrm{m}^{3} \cdot \mathrm{K}$ and increases along with heat conductivity.

Finally, the thermal resistance of MPP-PUFs was determined by mass loss after one month exposure at 150 , 175 , and $200{ }^{\circ} \mathrm{C}$ together with compressive strength before and after thermal exposure. Static measurements of thermal resistance showed that the largest mass loss was observed at first day of thermal exposure (Fig. 8). The obtained MPP-PUFs are rigid and remain as such after thermal exposure. The foams based on oligoetherol obtained from mMPP:EC $=1: 22$ deform at $200{ }^{\circ} \mathrm{C}$ in contrary to those obtained from MPP:EC:PC $=1: 10: 6$; the first were not tested for compressive strength after exposure. All obtained here MPP-PUFs are less thermally resistant than those obtained from oligoetherols synthesized from melamine and alkylene carbonates ${ }^{6}$ and obtained from carbazole, glycidol, and alkylene carbonates ${ }^{26}$. The mass loss of MPP-PUFs described here after 1 month thermal exposure at 150,175 , and $200{ }^{\circ} \mathrm{C}$ was $11.3-11.4 \%, 20.6-23.8 \%$ and $38.8 \%$, while those obtained from melamine and PC showed 6.7-8.7, 18.4-22.2, and 29.4-35.0\% mass loss ${ }^{6}$ or those obtained from carbazole, glycidol, and alkylene carbonates: 3.9-5.4, 8.9-10.1 and 17.9-23.4. ${ }^{26}$ Obtained MPP-PUFs have the compressive strength comparable to classic rigid PUFs. Their compressive strength increases upon thermal exposure at $150{ }^{\circ} \mathrm{C}$ and $175^{\circ} \mathrm{C}$, presumably due to additional residual cross-linking (Table 5, compositions 3 and 7). However upon exposure at $200{ }^{\circ} \mathrm{C}$ decrease of compressive strength was observed (Table 4, composition 7), though the compressive strength still remained larger than the initial one. Obviously, exposition of the MPP-PUF to $200{ }^{\circ} \mathrm{C}$ was accompanied by thermal degradation. 
Table 4. Properties of PUFs (continued)

\begin{tabular}{|c|c|c|c|c|c|c|}
\hline \multirow[t]{2}{*}{$\begin{array}{l}\text { Foams obtained } \\
\text { from oligoetherols }\end{array}$} & \multirow[t]{2}{*}{ MPP } & \multirow[t]{2}{*}{$\begin{array}{c}\text { No Comp } \\
\text { as in } \\
\text { Table } 3\end{array}$} & \multirow[t]{2}{*}{$\begin{array}{l}\text { Density } \\
{\left[\mathrm{kg} / \mathrm{m}^{3}\right]}\end{array}$} & \multicolumn{3}{|c|}{$\begin{array}{c}\text { Absorb. of Water } \\
\text { wt\% ] after }\end{array}$} \\
\hline & & & & $5 \mathrm{~min}$ & $3 \mathbf{h}$ & $24 \mathrm{~h}$ \\
\hline 1 & 2 & 3 & 4 & 5 & 6 & 7 \\
\hline mMPP:EC = 1:22 & 0 & 3 & $59.7 \pm 5.2$ & 1.7 & 3.6 & 5.6 \\
\hline mMPP: $\mathrm{EC}: \mathrm{PC}=1: 10: 6$ & 0 & 7 & $63.7 \pm 4.3$ & 3.8 & 7.1 & 11.4 \\
\hline \multirow{2}{*}{ mMPP:PC = 1:22 } & 45 & 11 & $79.0 \pm 7.2$ & 7.7 & 12.7 & 20.9 \\
\hline & 55 & 14 & $83.1 \pm 5.2$ & 7.2 & 12.4 & 17.5 \\
\hline \multirow{2}{*}{ mMPP: EC:PC = 1:10:6 } & 45 & 16 & $70.5 \pm 3.6$ & 7.3 & 10.7 & 15.4 \\
\hline & 55 & 19 & $85.5 \pm 4.7$ & 7.9 & 12.3 & 18.7 \\
\hline
\end{tabular}

Standard deviation in case of designation of Absorbtion of Water and Dimensional Stability does not exceed 1.8, and 1.4\%, respectively

Table 5. Thermal stability,compressive strength anfd flame properties of foam (continued)

\begin{tabular}{|c|c|c|c|c|c|c|}
\hline \multirow{2}{*}{$\begin{array}{c}\text { Foams } \\
\text { obtained from } \\
\text { oligoetherols }\end{array}$} & \multirow{2}{*}{ MPP } & \multirow{2}{*}{$\begin{array}{c}\text { No } \\
\text { Comp } \\
\text { as in } \\
\text { Table 3 }\end{array}$} & \multicolumn{3}{|c|}{$\begin{array}{l}\text { Mass loss in \% wt. after exposure } \\
\text { in one month in temperature }\left[{ }^{\circ} \mathrm{C}\right]\end{array}$} & \multirow{2}{*}{$\begin{array}{c}\text { before } \\
\text { exposure }\end{array}$} \\
\hline & & & 150 & 175 & 200 & \\
\hline 1 & & 2 & 3 & 4 & 5 & 6 \\
\hline mMPP:EC = 1:22 & 0 & 3 & $11.4 \pm 0.2$ & $23.8 \pm 0.1$ & - & $0.090 \pm 0.004$ \\
\hline mMPP:EC:PC = 1:10:6 & 0 & 7 & $11.3 \pm 0.1$ & $20.6 \pm 0.3$ & $38.8 \pm 0.3$ & $0.125 \pm 0.007$ \\
\hline \multirow{2}{*}{ mMPP:EC = 1:22 } & 45 & 11 & $15.0 \pm 0.3$ & $25.9 \pm 0.2$ & $33.7 \pm 0.2$ & $0.410 \pm 0.010$ \\
\hline & 55 & 14 & $13.3 \pm 0.2$ & $21.3 \pm 0.3$ & $34.7 \pm 0.2$ & $0.215 \pm 0.010$ \\
\hline \multirow{2}{*}{ mMPP:EC:PC = 1:10:6 } & 45 & 16 & $14.7 \pm 0.2$ & $24.4 \pm 0.3$ & $33.6 \pm 0.3$ & $0.201 \pm 0.008$ \\
\hline & 55 & 19 & $13.9 \pm 0.2$ & $20.9 \pm 0.2$ & $34.5 \pm 0.4$ & $0.259 \pm 0.05$ \\
\hline
\end{tabular}
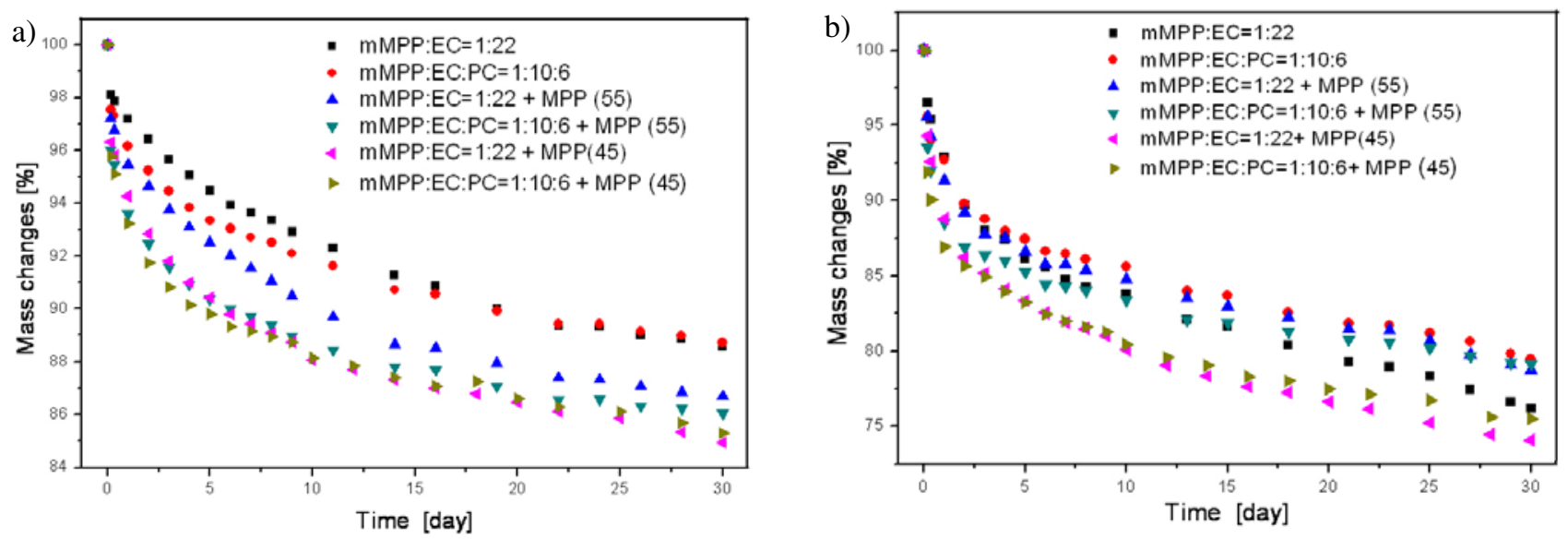

Fig. 8. Thermal stability of polyurethane foams as the mass changes after heating at 150 (a), 175 (b) and $200{ }^{\circ} \mathrm{C}$ (c) for one month (sample composition is given in insert)

Vertical flammability test indicated that MPP-PUFs obtained from oligoetherols based on MPP and alkylene carbonates were self-extinguishing (Table 5, composition 3 and 7, columns 10-12). In the test the flaming distance reached 34-35 mm from ignition line. Their flaming rate was low: $1.30-1.35 \mathrm{~mm} / \mathrm{s}$, while that of PUFs containing $1,3,5$-triazine ring was as high as $5.6-6.4 \mathrm{~mm} / \mathrm{s} .{ }^{27}$ Characte- ristically self-extinguishing was accompanied by low mass losses upon flaming: 4.9-7.5\% . However, their oxygen index was not very promising (21.9). Therefore further modification of powdered MPP-based PUFs was performed.

The MPP was additionally used as additive flame retardant. Effectively, as much as $45 \mathrm{~g}$ of MPP (per $100 \mathrm{~g}$ of oligoetherol) could be introduced into composition of 


\begin{tabular}{|c|c|c|c|c|c|c|c|}
\hline & & Stabil & in ter & $150^{\circ}$ & & & \\
\hline & & & & & & $\begin{array}{l}\text { Heat conductance } \\
\text { coefficient } \\
{[\mathrm{W} / \mathrm{m} \cdot \mathrm{K}]}\end{array}$ & $\begin{array}{c}\text { Heat } \\
\text { capacity } \\
{\left[\mathrm{kJ} / \mathrm{m}^{3} \cdot \mathrm{K} 10^{3}\right.}\end{array}$ \\
\hline $20 \mathrm{~h}$ & $40 \mathrm{~h}$ & $20 \mathrm{~h}$ & $40 \mathrm{~h}$ & $20 \mathrm{~h}$ & $40 \mathrm{~h}$ & & \\
\hline 8 & 9 & 10 & 11 & 12 & 13 & 14 & \\
\hline-1.6 & -2.1 & -3.9 & -4.9 & -6.7 & -7.6 & $0.0260 \pm 0.0005$ & $83.0 \pm 0.4$ \\
\hline-0.3 & -0.2 & -0.5 & -0.4 & -0.2 & -0.2 & $0.0430 \pm 0.0007$ & $111.0 \pm 1.0$ \\
\hline-0.7 & -0.7 & -0.2 & -.03 & -0.1 & -0.7 & $0.0378 \pm 0.0000$ & $115 \pm 1.3$ \\
\hline-0.1 & -0.7 & -0.1 & -0.4 & -0.1 & -0.5 & $0.0470 \pm 0.00010$ & $145 \pm 1.7$ \\
\hline-0.4 & -0.6 & -2.0 & -3.0 & -1.1 & -4.2 & $0.0370 \pm 0.0016$ & $148 \pm 1.9$ \\
\hline-0.5 & -0.6 & -0.1 & -0.3 & -0.1 & -0.3 & $0.0440 \pm 0.0006$ & $207 \pm 1.7$ \\
\hline
\end{tabular}

\begin{tabular}{|c|c|c|c|c|c|c|}
\hline \multicolumn{3}{|c|}{$\begin{array}{r}\text { Compressive strength [MPa]* } \\
\text { after exposure } \\
\text { in temperature }\end{array}$} & $\begin{array}{l}\text { Flame } \\
\text { zone } \\
{[\mathrm{mm}]}\end{array}$ & $\begin{array}{l}\text { Flame } \\
\text { rate } \\
{[\mathrm{mm} / \mathrm{s}]}\end{array}$ & $\begin{array}{l}\text { Mass loss } \\
\text { upon flaming } \\
\text { [\% mas.] }\end{array}$ & $\begin{array}{c}\text { Oxygen } \\
\text { index } \\
{[\%]}\end{array}$ \\
\hline 7 & 8 & 9 & 10 & 11 & 12 & 13 \\
\hline $0.157 \pm 0.005$ & $0.365 \pm 0.015$ & - & $34 \pm 3.0$ & $1.35 \pm 0.10$ & $7.5 \pm 0.9$ & $21.9 \pm 0.1$ \\
\hline $0.181 \pm 0.007$ & $0.216 \pm 0.011$ & $0.179 \pm 0.008$ & $35 \pm 2.0$ & $1.30 \pm 0.04$ & $4.9 \pm 0.5$ & $21.9 \pm 0.1$ \\
\hline $0.347 \pm 0.013$ & $0.025 \pm 0.009$ & $0.017 \pm 0.002$ & $6.0 \pm 0.5$ & - & $2.1 \pm 0.4$ & $23.8 \pm 0.2$ \\
\hline $0.583 \pm 0.010$ & $0.344 \pm 0.017$ & - & $5 \pm 0.5$ & - & $0.9 \pm 0.2$ & $24.2 \pm 0.1$ \\
\hline $0.181 \pm 0.05$ & $0.092 \pm 0.005$ & $0.017 \pm 0.001$ & $5.0 \pm 0.4$ & - & $3.0 \pm 0.2$ & $24.4 \pm 0.1$ \\
\hline $0.484 \pm 0.012$ & $0.202 \pm 0.007$ & - & $7.0 \pm 0.4$ & - & $1.5 \pm 0.2$ & $24.6 \pm 0.0$ \\
\hline
\end{tabular}

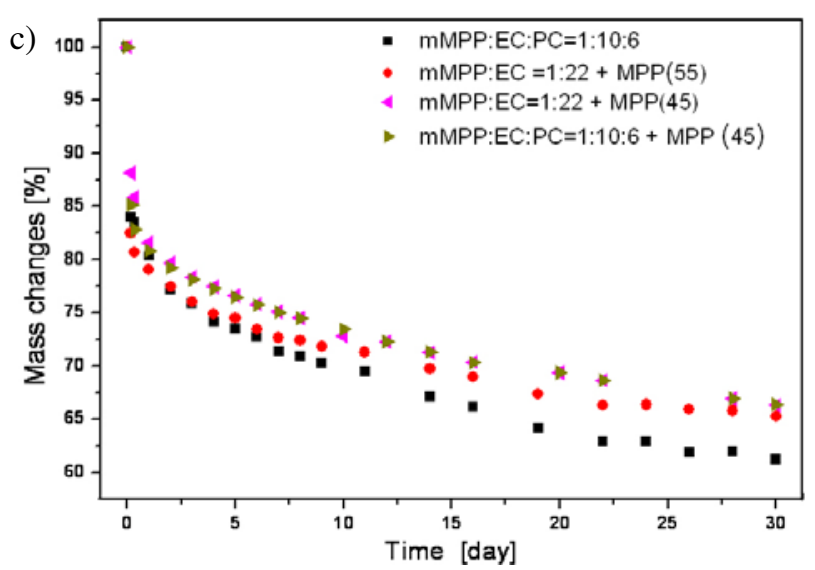

MPP-PUFs. Moreover, when MPP was grinded into $<75$ $\mu \mathrm{m}$ grain size, $55 \mathrm{~g}$ of MPP could be added (Table 3). Apparent density of those composites (MPP@ MPP-PUF) was $70.5-85.5 \mathrm{~kg} / \mathrm{m}^{3}$ and grew along with added MPP. Water uptake of composites was quite high; after 24 hours it reached 21\% (Table 4, compositions 11, 14, 16 and 19), while water uptake of MPP-PUFs was only below $11.4 \%$.
The water uptake increase of composite was due to presence of polar MPP physical admixture in composite. Linear dimension of composites do not change considerably upon thermal exposure; they are up to $4.2 \%$ after exposure at $150{ }^{\circ} \mathrm{C}$. Heat conductance coefficient of composites was $0.0370-0.0470 \mathrm{~W} / \mathrm{m} \cdot \mathrm{K}$ and increases along with MPP percentage in composite. It is generally larger than that of PUFs without MPP added as physical component, which might be consistent with higher water uptake of composites. Mass loss of composites MPP@ MPP-PUF upon thermal exposures at $150{ }^{\circ} \mathrm{C}, 175{ }^{\circ} \mathrm{C}$, and $200{ }^{\circ} \mathrm{C}$ are: $13.3-15.0 \%, 20.9-25.9 \%$, and $33.6-34.7 \%$, respectively (Table 5, compositions 11, 14, 16 and 19, columns 3-5). Moreover, the mass losses of composites do not depend on added MPP. However, they are higher than corresponding PUFs without additive MPP. The mass losses of composites upon exposition at $150 \mathrm{C}$ and $175^{\circ} \mathrm{C}$ are 4-5\% higher than those for MPP-PUFs. MPP@ MPPPUFs have considerably larger compressive strength than those of MPP-PUFs before thermal exposure. The composites MPP@ MPP-PUFs with $45 \mathrm{~g}$ MPP/100 g of oligoetherol in compositions do not deform upon heating at 200 ${ }^{\circ} \mathrm{C}$ in contrary MPP-PUFs. On the other hand these composites lose their compressive strength upon thermal exposure (Table 5, compositions 11 and 16). Composites 
with higher amount of added MPP (55 g /100 g oligoetherol) showed increase of compressive strength upon thermal exposure at $150{ }^{\circ} \mathrm{C}$ and sometimes $175^{\circ} \mathrm{C}$ (Table 5, compositions 14 and 19). The MPP@MPP-PUFs composites with the highest compressive strength determined by static method were monitored by dynamic measurements (Fig. 9, compositions 14 and 19). The highest thermal resistance indicated the foam MPP@MPP-PUFs obtained from oligoetherol based on MPP and EC and PC. Its 5\% mass loss was at $225{ }^{\circ} \mathrm{C}$, while that of MPP@ MPP-PUF obtained from oligoetherol based on MPP and EC was at $197{ }^{\circ} \mathrm{C}$. Maximum decomposition temperature of the best sample is spread over $350{ }^{\circ} \mathrm{C}-470{ }^{\circ} \mathrm{C}$ region. The residue mass after thermal exposure was $25-30 \%$ of initial mass (Fig. 9).

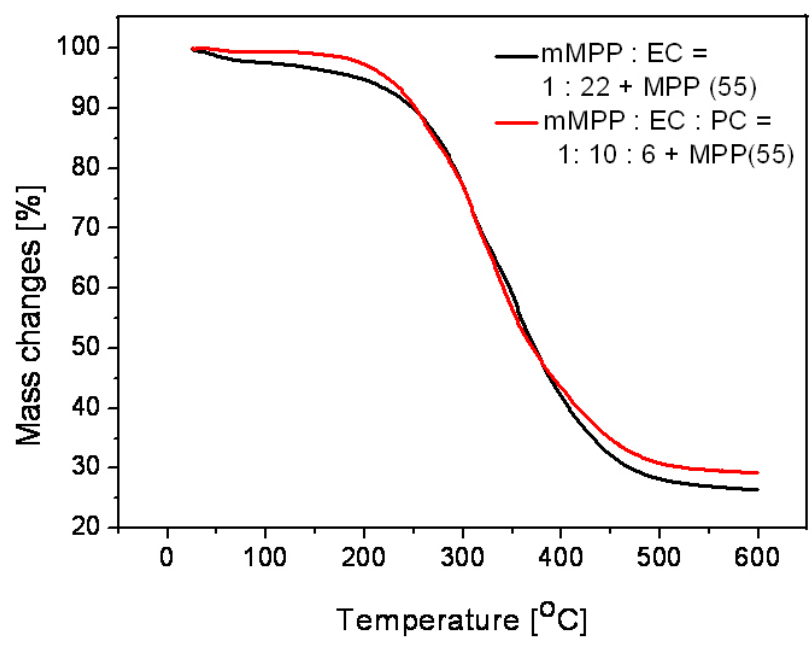

Fig. 9. MMass loss of PUFs measured thermogravimetrically (sample composition is given in insert).

Introduction of MPP as additive flame retardant into foaming mixture gave materials of considerably diminished flammability in comparison with MPP-PUFs. This was demonstrated both by decreased rate of flame and lower mass loss upon the end of the burning. All the studied foams were inflammable according to horizontal test (Table 5, columns 10-12). Flaming zone reached 5-7 mm; after ignition flame was removed the fire ceased. Mass loss during flaming test was at the level of $0.9-3.0 \%$.

According to general classification, the materials with oxygen index above 28 are considered as non flammable ${ }^{28}$. The oxygen index for composites MPP@MPP-PUFs was within 23.8-24.6, the value characteristic for self-distinguishing materials. ${ }^{28}$

\section{Conclusions}

1. The oligotherols containing 1,3,5-triazine ring and phosphorus were obtained from MPP and excess alkylene carbonates like EC and PC. The oligoetherols we- re suitable substrates to obtain thermally resistant polyurethane foams. Obtained polyurethane foams showed the increase of compressive strength upon thermal exposure and thermal resistance in comparison with PUFs obtained before ${ }^{6}$ from oligoetherols based on melamine and $\mathrm{PC}$.

2. Addition of MPP into foaming mixture containing above mentioned oligoetherols gave composites, from which polyurethane foams were formed. The composite foams were self-extinguishing or non-flammable materials with oxygen index 24.2-24.6 and with increased thermal resistance. The optimized amount of added flame retardant was $55 \mathrm{~g}$ per $100 \mathrm{~g}$ oligoetherol, i.e. 20 mass $\%$ in foaming composition.

3. Obtained polyurethane foams have high thermal resistance and stand long lasting thermal exposure even at $200 \mathrm{C}$. Their compressive strength depends on kind of alkylene carbonate used. Higher compressive strength show the foams obtained usually from oligoetherol with both oxyethylene and oxypropylene units.

\section{Acknowledgments}

\section{NMR spectra were recorded within U-8689/DS}

\section{References}

1. M. Kucharski, D. Kijowska, J. Appl. Polym. Sci., 2001, 80, 1776-1784. http://dx.doi.org/10.1002/app.1273

2. M. Kucharski, D. Kijowska, J. Appl. Polym. Sci., 2003, 89, 104-115. http://dx.doi.org/10.1002/app.12065

3. D. Kijowska, M. Kucharski, J. Appl. Polym. Sci,. 2004, 94, 2302-2308. http://dx.doi.org/10.1002/app.21165

4. Z. Wirpsza, Polyurethane, WNT, Warsaw, Poland, 1991.

5. A. Prociak, G. Rokicki, J. Ryszkowska, Polyurethane materials PWN, Warsaw, Poland 2014.

6. J. Lubczak, E. Chmiel-Szukiewicz, J. Duliban, D. GłowaczCzerwonka, R. Lubczak, B. Łukasiewicz, I. Zarzyka, A. Łodyga, P. Tyński, D. Minda-Data, M. Kozioł, Z. Majerczyk, Przemysł Chemiczny, 2014, 93, 1690-1697.

7. H. Goodman, Handbook of Thermoset Plastics, Second Edition, William Andrew Pulishing/Noyes, New Jersej.US, 1999.

8. C. J. Hilado, Flammability Handbook for Plastics, Technomic Publishing Company, Inc. 1998.

9. D. Ż uchowska, Construction polymers, WNT, Warsaw, Poland, 2000.

10. Z. Brzozowski, D. Kijeńska, W. Zatorski, Plastics Review, 2001, 9, 65-67.

11. P. Gijsman, R. Steenbakkers, C. Furst, J. Kersjes, Polym. Degrad. Stab., 2002, 78, 219-224 . http://dx.doi.org/10.1016/S0141-3910(02)00136-2

12. C. Wilkie, A. Morgan A., Fire Retardancy of Polymeric Materials, Boca Raton, London, New York, CRC Press 2009. 
13. B. Cichy, D. Łuczkowska, M. Nowak, M. Władyka-Przybylak, Ind. Eng. Chem. Res., 2003, 42, 2897-2905. http://dx.doi.org/10.1021/ie0208570

14. S. Fuchs, T. Weiss, U. S. Patent Number 8,877,838, 2014.

15. D. Kijowska, S. Wołowiec, J. Lubczak, J. Appl. Polym Sci., 2004, 93, 294-300. http://dx.doi.org/10.1002/app.20453

16. Polyethers for polyurethanes. Test methods. Determination of hydroxyl value, Polish (European) Standards PN-C-8905203:1993P, Polish Committee for Standardization 1993.

17. Cellular Plastics and Rubbers. Determination of apparent (bulk) Density, Polish (European) Standards PN-EN ISO 845-2000. Ed. Polish Committee for Standardization.

18. Cellular Plastics, rigid. Determination of Water Absorption. Polish (European) Standards PN-EN ISO 2896-1986. Ed. Polish Committee for Standardization.

19. Cellular Plastics, rigid. Test of dimensional Stability. Polish (European) Standards PN-EN ISO 2796-1986. Ed. Polish Committee for Standardization.

20. Cellular Plastics, Compression Test for rigid Materials. Polish (European) Standards PN- EN ISO 844-1978, Ed. Polish Committee for Standardization.
21. Plastics - Determination of burning behavior by oxygen index - Part 2. Ambient-temperature test. Polish (European) Standards PN-EN ISO 4589-2. 2006. Ed. Polish Committee for Standardization.

22. Flexible Cellular polymeric Materials - Laboratory Characteristics of small specimens Subject to a small Flame. Polish (European) Standards PN-EN ISO 3582-2002. Ed. Polish Committee for Standardization.

23. J. Lubczak, M. Kucharski, Chemia Stos., 1985, 29, 277-287.

24. J. Lubczak, Polimery, 2011, 56, 452-460.

25. E. Węglowska, J. Lubczak, J. Appl. Polym Sci., 2005, 98, 2130-2138. http://dx.doi.org/10.1002/app.22383

26. R. Lubczak, J. Cell. Plast., 2015, 34, 15-25.

27. J. Lubczak, B. Łukasiewicz, B. Myśliwiec, J. Appl. Polym. Sci, 2013, 127, 2057-2066. http://dx.doi.org/10.1002/app.37738

28. J. M. Cogen, T. S. Lin, R. E. Lyon, Fire Mater. 2009, 33 , 33-50. http://dx.doi.org/10.1002/fam.980

\section{Povzetek}

Melamin polifosfat je bil uporabljen kot reaktivni in aditivni zaviralec ognja za pripravo termično obstojnih poliuretanskih pen. Melamin polifosfat smo hidroksialkilirali z etilen in propilen karbonati, da bi dobili oligoeterole z obroči 1,3,5 - triazina in fosforja. Preučevali smo strukturo in fizikalne lastnosti produktov. Poliuretanske pene, pripravljene iz teh oligoeterolov so bile samougasljive. Dodajanje prahu melanin polifosfata $v$ peno je povzročilo nadaljnje upadanje vnetljivosti modificirane poliuretanske pene. Modificiranim poliuretanskim penam smo s fizikalnimi metodami določili termično obstojnost in vnetljivost. Najvišja določena vrednost indeksa kisika modificirane poliuretanske pene je bila 24,6. Vse modificirane poliuretanske pene so bile zelo termično obstojne tudi pri daljši izpostavljenosti višjim temperaturam $\left(200^{\circ} \mathrm{C}\right)$. 